\title{
Influence of tubercle aggregate size on severity of adjuvant arthritis in the rat
}

\author{
S. P. LIYANAGE, H. L. F. CURREY, AND B. VERNON-ROBERTS \\ From the Bone and Joint Research Unit, The London Hospital Medical College
}

\begin{abstract}
Liyanage, S. P., Currey, H. L. F., and Vernon-Roberts, B. (1975). Annals of the Rheumatic Diseases, 37, 49. Influence of tubercle aggregate size on severity of adjuvant arthritis in the rat. Incorporation into Freund's complete adjuvant of tuberculous aggregates smaller than $90 \mu \mathrm{m}$ in size is essential to produce adjuvant arthritis in the rat, and this correlates with a significantly greater degree of cell-mediated immunity to tuberculous antigens produced by small aggregates $(<90 \mu \mathrm{m})$, when compared with large $(>90 \mu \mathrm{m})$ aggregates. This requirement for small aggregates to render Freund's complete adjuvant arthritogenic is not paralleled by detectable differences in antimycobacterial humoral antibody production nor by a size-dependent requirement for a conventional adjuvant effect.
\end{abstract}

Adjuvant disease in the rat is induced by the intradermal injection of a suspension of aggregated killed tubercle bacilli in oil. Results showing that mycobacterial aggregates finely ground in an agate mortar and dispersed in mineral oil produce severe lesions more frequently than mycobacteria less finely ground in a porcelain mortar (Fujihara, Mori, and Nakazawa, 1970) suggest that the size of aggregate used influences the induction of adjuvant arthritis. It has been postulated (Waksman, Pearson, and Sharp, 1960; Quagliata and Phillips-Quagliata, 1972) that adjuvant arthritis represents a cell-mediated reaction to tuberculous material reaching the joints from the original injection site. Thus, the use of aggregates of different size could determine differences in the transport of mycobacterial antigen to the joints and/or the pattern of immunological responses and reactions.

We have studied the ability of tubercle aggregates of different sizes to induce adjuvant arthritis and humoral and cell-mediated immune responses to tuberculous antigens, and the influence of aggregate size on the conventional adjuvanticity of Freund's complete adjuvant (FCA).

\section{Materials and methods}

PREPARATION OF ADJUVANTS

Dried, heat-killed Mycobacterium tuberculosis, mixed strains C, DT, and PN (Central Veterinary Laboratory, Weybridge) were thoroughly ground with a mortar and pestle, and the aggregates of clumped bacteria separated according to size using a series of metal test sieves (Endecotts Ltd.) having aperture sizes 45, 63, 90, 180, 250 , and $360 \mu \mathrm{m}$. Aggregate size was confirmed by direct microscopical measurement, both before and after suspension in heavy mineral oil as FCA.

Accepted for publication May 13, 1974.
ARTHRITIS

Sprague-Dawley rats weighing 200-250 g were used throughout, and arthritis was induced by an intradermal injection of FCA into the right hindfoot pad. The polyarthritis was assessed by scoring the joints daily (Currey and Ziff, 1966). Control animals were injected with incomplete adjuvant not containing mycobacteria. All experimental groups contained at least 6 animals.

DELAYED SKIN RESPONSES TO TUBERCULOUS ANTIGENS

Delayed skin responses to tuberculous antigens were assessed by measuring the increase in ear thickness 24 hours after the intradermal injection of $0.02 \mathrm{ml}$ PPDtuberculin $(0.2 \mathrm{mg} / \mathrm{ml})$ or whole tuberculous material $(1 \mathrm{mg} / \mathrm{ml}$ in saline) on day +14 .

\section{In vitro LYMPHOCYTE STUDIES}

\section{Separation of lymphocytes}

Total and differential leucocyte counts were performed on the peripheral blood at the end of each experiment. Almost pure populations of lymphocytes were obtained from peripheral blood and spleen cells by incubation with Plasmagel (Laboratoire Roger Bellon, Neuilly) to remove erythrocytes, followed by centrifugation in a mixture of Ficoll (Pharmacia, Sweden) and triosyl '75' (Glaxo Laboratories, England) to separate the lymphocytes from the other leucocytes. The details of the technique have been described elsewhere by Vernon-Roberts, Currey, and Perrin (1974).

\section{Macrophage migration}

Spleen lymphocytes were obtained on day +14 from rats given large or small aggregates in FCA, or incomplete adjuvant. $2 \times 10^{6}$ viable lymphocytes were incubated in Medium 199 (Wellcome) containing penicillin 200 units $/ \mathrm{ml}$, streptomycin $100 \mu \mathrm{g} / \mathrm{ml}$, and $10 \%$ fetal calf serum. PPD was added to each culture at a concentration of $30 \mu \mathrm{g} / \mathrm{ml}$. Control suspensions did not have PPD added. After 48 hours of culture the cells were discarded and the 
cell-free supernatants were filtered through a millipore filter (pore size $0.22 \mu \mathrm{m}$ ) to exclude bacterial contamination. The presence of macrophage migration inhibitory factor (MIF) in the supernatants was assessed by using the supernatants to fill the chambers of leucocyte migration plates (Sterilin) which contained microhaematocrit tubes previously packed with donor rat peritoneal macrophages. The areas of macrophage migration were assessed by the technique of Revell, Dean, Vernon-Roberts, Muir, and Marshall (1972).

\section{Lymphocyte transformation}

Blast-cell transformation of lymphocytes derived from peripheral blood or spleen on day +14 was assessed by a modification (Revell and others, 1972) of the method of Janossy and Greaves (1971). Phytohaemagglutinin (PHA) (Wellcome) was added to the lymphocyte cultures at a concentration of $100 \mu \mathrm{g} / \mathrm{ml}$ and blast-cell transformation assessed by measuring ${ }^{3} \mathrm{H}$-thymidine incorporated during DNA synthesis.

\section{Membrane immunofluorescent staining \\ Lymphocytes derived from blood or spleen were incubated in fluorescein-labelled rabbit anti-rat immunoglobulin (Wellcome Research Laboratories) at 1/5 and 1/10 dilution. The conjugate was de-aggregated by ultra- centrifugation before use and its specificity checked by standard methods. The presence of membrane immuno- fluorescent staining was examined in 500 cells in each preparation by epi-illumination with a Zeiss photo- microscope using an ultraviolet light source. The details of the technique used have been described by Vernon- Roberts and others (1974).}

\section{ANTIMYCOBACTERIAL ANTIBODIES}

Antimycobacterial antibodies were sought using the passive haemagglutination technique of Perper, Oronsky, and Blancuzzi (1972). We failed to show any such antibodies when the FCA employed as challenge was constituted with a human strain of Myco. tuberculosis. However, using FCA constituted with Mycobacterium butyricum as a challenge and soluble mycobacterial antigen (kindly provided by Dr. Robert Perper), we were able to detect antimycobacterial antibodies. FCA constituted with Myco. butyricum was therefore employed for this part of the study.

CONVENTIONAL ADJUVANTICITY OF FCA

The adjuvanticity of FCA in relation to tubercle aggregate size was studied using heat-aggregated human serum albumin (HSA). An emulsion of equal volumes of HSA in saline $(10 \mathrm{mg} / \mathrm{ml})$ and liquid paraffin was prepared and tubercle aggregates of different sizes were added to give a final concentration of $1 \mathrm{mg} / \mathrm{ml}$. Each hindfoot pad was injected with $0.05 \mathrm{ml}$ of emulsion or with a control substance as indicated in Table X. Passive haemagglutination tests were carried out on blood specimens obtained on day +7 and day +14 , the antigen (HSA) being coupled to sheep erythrocytes using tannic acid. Delayed skin tests were performed on day +14 by injecting $0.02 \mathrm{ml}$ of an $0.2 \%$ solution of $\mathrm{HSA}$ in saline, measuring the increase in ear thickness 24 hours later.

\section{Results}

\section{ARTHRITIS}

Tubercle aggregates smaller than $90 \mu \mathrm{m}$ were essential to produce arthritis (Table I). Larger aggregate adjuvant consistently failed to induce arthritis and permitted normal weight gain of the

Table I Arthritogenicity of tubercle aggregates $<90 \mu \mathrm{m}$ and $>90 \mu \mathrm{m}$ incorporated into $\mathrm{FCA}$

\begin{tabular}{|c|c|c|c|}
\hline $\begin{array}{l}\text { Aggregate } \\
\text { size } \\
(\mu \mathrm{m})\end{array}$ & $\begin{array}{l}\text { Mean weight } \\
\text { change from } \\
\text { day } 0 \text { to } \\
\text { day }+14(\mathrm{~g})\end{array}$ & $\begin{array}{l}\text { Incidence of } \\
\text { arthritis }\end{array}$ & $\begin{array}{l}\text { Mean joint } \\
\text { score on } \\
\text { day }+14\end{array}$ \\
\hline$<90$ & -13 & $6 / 6$ & $14 \cdot 2$ \\
\hline$>90$ & +25 & $0 / 6$ & 0 \\
\hline
\end{tabular}

animals. When the animals were injected with a mixture of an arthritogenic dose of small aggregate FCA and an equal amount of large aggregate FCA, there was a definite but very variable reduction in the incidence and severity of arthritis (compared with that produced by small aggregate FCA alone). There was no evidence that aggregates in the range of 45-63 $\mu \mathrm{m}$ produced a more intense arthritis than those of $63-90 \mu \mathrm{m}$ (Table II). Varying the concentration of 45-63 $\mu \mathrm{m}$ aggregates (Table III) and volume of FCA showed that marked arthritis was induced by injecting $0.01 \mathrm{ml}$ FCA at a concentration of $6 \mathrm{mg} / \mathrm{ml}$ (Table IV), and this was used as the standard method of inducing arthritis in subsequent experiments. For comparison, other groups were given $0.01 \mathrm{ml}$ FCA prepared from aggregates of $180-250 \mu \mathrm{m}$ at a concentration of $6 \mathrm{mg} / \mathrm{ml}$. In the experiments which follow, the term 'small aggregates' refers to material in the size range $45-63 \mu \mathrm{m}$ and 'large aggregates' to material in the size range $180-250 \mu \mathrm{m}$.

\section{CELL MEDIATED IMMUNE RESPONSES TO}

TUBERCULOUS ANTIGENS

One in vivo and one in vitro test were performed. Skin testing on day +14 showed that significantly greater delayed skin responses to both PPD-tuberculin and whole tuberculous material developed in animals which had received small aggregates (Table V). Skin testing of animals injected with a mixture of small and large aggregates showed variable responses,

Table II Arthritogenicity of aggregates $<90 \mu \mathrm{m}$

\begin{tabular}{ll}
\hline $\begin{array}{l}\text { Aggregate size } \\
(\mu \mathrm{m})\end{array}$ & $\begin{array}{l}\text { Mean joint score } \\
\text { on day }+15\end{array}$ \\
\hline $45-63$ & $\frac{22 \cdot 5}{18 \cdot 2}$ \\
\hline $63-90$ & $\frac{22}{4}$ \\
\hline
\end{tabular}


Table III Arthritogenicity of $0.05 \mathrm{ml}$ of various concentrations of 45-63 $\mu \mathrm{m}$ tubercle aggregates in FCA

\begin{tabular}{ll}
\hline $\begin{array}{l}\text { Concentration of } \\
\text { mycobacteria }(\mathrm{mg} / \mathrm{ml})\end{array}$ & $\begin{array}{l}\text { Mean joint score } \\
\text { on day }+15\end{array}$ \\
\hline 2 & $\frac{6.0}{6.0}$ \\
\hline 4 & $\frac{6.0}{10.0}$ \\
\hline
\end{tabular}

Table IV Arthritogenicity of various volumes of FCA containing 45-63 $\mu \mathrm{m}$ tubercle aggregates $(6 \mathrm{mg} / \mathrm{ml})$

\begin{tabular}{ll}
\hline $\begin{array}{l}\text { Volume of FCA } \\
(\mathrm{ml})\end{array}$ & $\begin{array}{l}\text { Mean joint score } \\
\text { on day }+15\end{array}$ \\
\hline 0.01 & $\frac{15.0}{18.5}$ \\
\hline 0.025 & $\frac{15.8}{0.05}$
\end{tabular}

tending to be intermediate between those obtained with small or large aggregate injections alone. There was significant production of macrophage migration inhibitory factor by spleen lymphocytes incubated with PPD when the lymphocytes were obtained from

Table $\mathrm{V}$ Effect of aggregate size on subsequent delayed skin response to PPD and whole tubercle bacilli $(T B C)$ tested on day +14

\begin{tabular}{|c|c|c|}
\hline \multirow{2}{*}{$\begin{array}{l}\text { Size of aggregate } \\
\text { in FCA injected } \\
\text { on day } 0 \\
(\mu m)\end{array}$} & \multicolumn{2}{|c|}{$\begin{array}{l}\text { Increase in ear thickness at } \\
24 \text { hours }(\mathrm{mm})\end{array}$} \\
\hline & $P P D$ & $T B C$ \\
\hline $45-63$ & $0.44(\mathrm{P}<0.001)$ & $0.45(\mathrm{P}<0.01)$ \\
\hline $180-250$ & $0.09(P<0.5)$ & $0.21(\mathrm{P}<0.05)$ \\
\hline $\begin{array}{l}\text { Incomplete } \\
\text { adjuvant (no } \\
\text { aggregate) }\end{array}$ & 0.01 & $0 \cdot 14$ \\
\hline
\end{tabular}

animals given the small aggregates, whereas the large aggregate group showed no response (Table VI).

Table VI Effect of aggregate size on subsequent production of macrophage migration inhibitory factor by rat spleen lymphocytes tested on day +14 in response to PPD

\begin{tabular}{ll}
\hline $\begin{array}{l}\text { Size of aggregate in } \\
F C A \text { injected on day } 0 \\
(\mu \mathrm{m})\end{array}$ & $\begin{array}{l}\text { Percentage inhibition of } \\
\text { macrophage migration }\end{array}$ \\
\hline $45-63$ & $38(\mathrm{P}<0.01)$ \\
\hline $180-250$ & $\frac{14(\mathrm{P}>0.9)}{4}$ \\
\hline $\begin{array}{l}\text { Incomplete adjuvant } \\
\text { (no aggregate) }\end{array}$ & 0 \\
\hline
\end{tabular}

BLAST-CELL TRANSFORMATION OF LYMPHOCYTES IN RESPONSE TO PHA STIMULATION

Peripheral blood lymphocytes obtained on day +14 from rats given small aggregates showed an increased uptake $(\mathrm{P}<0 \cdot 1)$ of ${ }^{3} \mathrm{H}$-thymidine when incubated with PHA. There was less marked uptake of ${ }^{3} \mathbf{H}$ thymidine by lymphocytes from rats given large aggregates (Table VII). Similar results were obtained using spleen lymphocytes.

Table VII Effect of aggregate size on subsequent blast cell transformation of peripheral blood lymphocytes tested on day +14 in response to PHA stimulation

Size of aggregate in

$F C A$ injected on day 0 $(\mu \mathrm{m})$

$\frac{45-63}{180-250}$

Incomplete adjuvant (no aggregate)
Percentage incorporation of ${ }^{3} H T$ during $P H A$ stimulation

$773(\mathrm{P}<0.1)$

$489(\mathrm{P}<0.2)$

100

Table VIII Effect of aggregate size on peripheral blood lymphocytes studied on day +14

\begin{tabular}{|c|c|c|c|c|c|}
\hline \multirow{2}{*}{$\begin{array}{l}\text { Size of aggregate in } \\
F C A \text { injected on day } 0 \\
(\mu \mathrm{m})\end{array}$} & \multirow[t]{2}{*}{$\begin{array}{l}\text { Lymphocytes } \\
\times 10^{-3} / \mu l\end{array}$} & \multicolumn{2}{|c|}{$\begin{array}{l}\text { Lymphocytes bearing surface Ig } \\
\text { (B-cells) }\end{array}$} & \multicolumn{2}{|c|}{ Lymphocytes without surface Ig } \\
\hline & & $\%$ & $\times 10^{-3} / \mu l$ & $\%$ & $\times 10^{-3} / \mu l$ \\
\hline $45-63$ & $13 \cdot 3$ & $11 \cdot 4$ & $1 \cdot 5^{*}$ & $88 \cdot 6$ & $11 \cdot 8$ \\
\hline $180-250$ & $14 \cdot 9$ & $13 \cdot 3$ & $2 \cdot 0$ & $86 \cdot 7$ & 12.9 \\
\hline $\begin{array}{l}\text { Incomplete adjuvant } \\
\text { (no aggregate) }\end{array}$ & $15 \cdot 1$ & $17 \cdot 5$ & $2 \cdot 6$ & $82 \cdot 5$ & $12 \cdot 5$ \\
\hline
\end{tabular}


PERIPHERAL BLOOD LYMPHOCYTES

On day +14 the number of circulating cells bearing demonstrable surface immunoglobulin (presumably B-cells) was significantly reduced in the small aggregate group (Table VIII). No changes in the absolute or percentage distribution of lymphocytes not possessing demonstrable surface immunoglobulin (presumably predominantly T-cells) were observed.

HUMORAL ANTIBODY RESPONSES TO SOLUBLE MYCOBACTERIAL ANTIGEN

The antibody titres to Myco. butyricum on day +7 and day +13 were not different in groups of rats given small or large aggregates (Table IX). Attempts to detect humoral antibodies in animals which had received human strains were unsuccessful (see Materials and methods).

Table IX Effect of aggregate size on humoral antibody response to Myco. butyricum detected by passive haemagglutination

\begin{tabular}{|c|c|c|}
\hline \multirow{2}{*}{$\begin{array}{l}\text { Size of aggregate in } \\
F C A \text { injected on day } 0 \\
(\mu m)\end{array}$} & \multicolumn{2}{|c|}{ Antibody titre $\left(-\log _{2}\right)$} \\
\hline & Day +7 & Day +13 \\
\hline $45-63$ & $1 \cdot 2$ & $2 \cdot 5$ \\
\hline $180-250$ & $1 \cdot 0$ & $2 \cdot 3$ \\
\hline $\begin{array}{l}\text { Incomplete adjuvant } \\
\text { (no aggregate) }\end{array}$ & 0 & 0 \\
\hline
\end{tabular}

CONVENTIONAL ADJUVANTICITY

The influence of tubercle aggregate size on the conventional adjuvanticity of FCA in respect of delayed skin responses and humoral antibody titres to aggregated human serum albumin was assessed (Table X), and it was found that the administration of either small or large aggregates augmented the response to an equal extent.

\section{Discussion}

It is known that adequate grinding of tuberculous material is essential for the consistent production of severe adjuvant arthritis in the rat. The experiments described in this paper establish that this requirement is due to the necessity for aggregates of the material to be $90 \mu \mathrm{m}$ or less in diameter. Admixture of large aggregates appears to have an inhibitory effect on the incidence and severity of the arthritis.

The experiments described do not elucidate the exact mechanism by which size dependence operates, but the data provide interesting clues in this regard. If, as Waksman and others (1960) and Quagliata and Phillips-Quagliata (1972) suggest, adjuvant arthritis represents a cell-mediated reaction to tuberculous material which has reached the joints from the site of injection, then aggregate size might modify the migration of antigen to the joints or influence overall or specific immunity. In this connexion we are at present studying the influence of aggregate size on the transport and distribution of tuberculous material.

Regarding the effects of aggregate size on immune reactions, there appears to be a clear parallelism between the requirement for smaller aggregates to induce arthritis and to induce strong delayed skin responses to tuberculin and other tuberculous antigens. By contrast, we have found that antituberculous humoral antibody production, judged by the soluble mycobacterial antigen employed here, appears to be independent of aggregate size. These data, therefore, would clearly be in keeping with aggregate size influencing the incidence of adjuvant arthritis by modifying the development of cell-mediated immunity to tuberculous antigens. Moreover, there is evidence that antimycobacterial antibodies are not pathogenic in this experimental model (Perper and Oronsky, 1972).

The in vivo delayed skin responses to PPD were

Table $\mathbf{X}$ Effect of aggregate size on adjuvanticity of FCA: delayed skin responses and humoral antibody titres to human serum albumin (HSA)

\begin{tabular}{|c|c|c|c|}
\hline \multirow[t]{2}{*}{ Material injected on day 0} & \multirow{2}{*}{$\begin{array}{l}\text { Increase in ear thickness } \\
\text { at } 24 \text { hours }(\mathrm{mm}) \\
(\text { day }+14)\end{array}$} & \multicolumn{2}{|c|}{ Antibody titres to $\mathrm{HSA}\left(-\log _{2}\right)$} \\
\hline & & Day +7 & Day +14 \\
\hline HSA in FCA with $45-63 \mu \mathrm{m}$ & $0 \cdot 650^{*}$ & $1 \cdot 2$ & $3 \cdot 6 \ddagger$ \\
\hline HSA in FCA with $180-250 \mu \mathrm{m}$ & $0 \cdot 711^{*}$ & $0 \cdot 7$ & $3 \cdot 4 \ddagger$ \\
\hline HSA in incomplete adjuvant & $0 \cdot 315 \dagger$ & 0 & $0 \cdot 8$ \\
\hline HSA in saline & $0 \cdot 226$ & 0 & 0 \\
\hline Non-injected controls & $0 \cdot 150$ & 0 & 0 \\
\hline
\end{tabular}


accompanied by in vitro evidence for a state of delayed-type hypersensitivity to PPD assessed by macrophage migration inhibition. The interpretation of the other in vitro tests carried out in this study is a matter for speculation. Blast transformation in response to PHA stimulation is thought to be a ' $T$ '-cell reaction. The tendency shown here for the prior injection of FCA (particularly that containing smaller sized aggregates) to increase the percentage of lymphocytes undergoing blast transformation might suggest some overall increase in numbers of 'transformable' ' $\mathrm{T}$ '-cells in the peripheral blood and spleens of these animals. However, judged by the one test applied here (absence of cell membrane staining for immunoglobulin), the total numbers of peripheral blood ' $T$ '-cells appeared to be unaffected by the FCA injection.

Having shown the marked differences in arthritogenicity and cell-mediated immunity produced by varying the size of tubercle aggregate in FCA, it appeared of interest to test whether this sizedependence extended also to the conventional adjuvant properties of FCA, i.e. the ability to augment an immune response to another antigen injected at the same time. However, using heataggregated human serum albumin as antigen, we have been unable to show differences between the adjuvant potency of FCA made up with small-sized aggregates and that made up with larger aggregates when assessed by delayed skin responses and humoral antibody titres. It is of interest that recent studies by Koga and Pearson (1973) suggest that the fraction of mycobacteria which is responsible for arthritogenicity can be separated chemically from that which endows FCA with its conventional adjuvanticity.

Our thanks are due to Dr. Robert Perper for kind assistance in connexion with the mycobacterial antibody studies. This work was supported by the Arthritis and Rheumatism Council.

\section{References}

Currey, H. L. F., AND ZIFF, M. (1966) Lancet, 2, 889 (Suppression of experimentally induced polyarthritis in the rat by heterologous anti-lymphocyte serum)

Fujihara, E., Mori, T., AND NaKazawa, M. (1970) Pharmacometrics, 4, 897 (Studies on adjuvant disease. I. Induction of the disease)

JaNossy, G., AND Greaves, M. F. (1971) Clin. exp. Immunol., 9, 483 (Lymphocyte activation. I. Responses of T and B lymphocytes to phytomitogens)

Koga, T., AND PeArson, C. M. (1973) J. Immunol., 111, 599 (Immunogenicity and arthritogenicity in the rat of an antigen from Mycobacterium tuberculosis wax I)

PerPer, R. J., AND OrONSKY, A. L. (1972) Nature (New Biol.), 238, 23 (Serum factor protecting against experimental arthritis)

- - - AND BlancuzzI, V. (1972) Arthr. and Rheum., 15, 283 (Antibody to mycobacterial antigens in adjuvant arthritis. I. Relationship to disease and delayed hypersensitivity)

Quagliata, F., ANd Phillips-Quagliata, J. M. (1972) Cellular Immunol., 3, 78 (Competence of thoracic duct cells in the transfer of adjuvant disease and delayed hypersensitivity. Evidence that mycobacterial components are required for the successful transfer of the disease)

Revell, P. A., Dean, M. F., Vernon-Roberts, B., Mutr, H., and Marshall, A. H. E. (1972) Int. Arch. Allergy, 43, 813 (Inhibition of macrophage migration by a proteoglycan extracted from Kurloff cells of the guinea-pig)

Vernon-Roberts, B., Currey, H. L. F., AND Perrin, J. (1974) Ann. rheum. Dis., 33, 430 (T and B cells in the blood and synovial fluid of rheumatoid patients)

Waksman, B. H., Pearson, C. M., AND Sharp, J. T. (1960) J. Immunol., 85, 403 (Studies of arthritis and other lesions induced in rats by injection of mycobacterial adjuvant. II. Evidence that the disease is a disseminated immunologic response to exogenous antigen) 